\title{
福島県勿来海岸における東北地方太平洋沖地震津波による 大規模土砂移動と海岸地形変化
}

\section{L arge-scale Sand Transport and B each D eformation of Nakoso Coast in Fukushima Prefecture due to the 2011 Tohoku Tsunami}

\author{
大村森香 $^{1} \cdot$ 下園武範 ${ }^{2} \cdot$ 佐藤愼司 $^{3}$ \\ M orika OHM URA, Takenori SHIM OZONO and Shinji SATO
}

\begin{abstract}
Large-scale sand movement due to the 2011 Tohoku Tsunami was investigated for the Nakoso Coast, Fukushima Prefecture, by using analysis of bathymetry surveys combined with beach deformation simulation. Significant beach deformation was observed in the north area where many seawalls were destroyed. In contrasts, the sand movement due to tsunami was small in the south area, where the coast is protected by shore-parallel detached breakwaters, The offshore sand loss was found to be small since the sand movement due to tsunami was mostly confined in the nearshore area shallower than the closure depth. The total sand loss on the Nakoso Coast was found to be estimated by the co-seismic tectonic subsidence of the order of $40 \mathrm{~cm}$. However, a non-negligible loss of sand was found in the sand transport to the river.
\end{abstract}

\section{1はじめに}

2011 年東北津波では，津波とともに大量の土砂が移動 し，海岸が大きく変形した，例えば仙台海岸では，干潟 砂州が津波により多数決壊していることや, 大規模な海 岸侵食が生じたことなどが報告されている。これらの多 くは, 回復途上にあるものの, 回復度合いは海岸の波浪 条件や土砂収支などさまざま影響があり一様ではない. 今後, 津波以前の地形まで回復するかどうかについては, 長期のモニタリング調査の結果を待たねばならない，本研 究では, 大規模な砂州の変形が見られた福島県南部の勿 来海岸において津波による海浜地形変化機構を解明する ことを目的とし, 航空写真から津波による砂州の変化の 様子を把握した上で, 深浅測量デー夕に基づき総土砂量 変化を解析し, 数值計算の結果と比較し, 考察を行った.

\section{2 勿来海岸の地形変化}

\section{(1) 勿来海岸の概要}

本研究の対象地である勿来海岸は, 福島県南部に位置 する全長約 $7 \mathrm{~km}$ のポケットビーチで, 流域面積 $600 \mathrm{~km} の$ 鮫川からの土砂供給が主要な漂砂源である。鮫川河口以 南の海岸は侵食傾向にあり, 人工リーフや離岸堤が設置 されている．鮫川河口部と左岸には大規模な砂州が発達 して抢り, 鮫川河口左岸には仕切り堤と左岸砂州に常磐

\begin{tabular}{lll}
\hline 1 学生会員 & & $\begin{array}{l}\text { 東京大学大学院工学系研究科社会基盤学 } \\
\text { 専攻 }\end{array}$ \\
2 正会員 & 博(工) & $\begin{array}{l}\text { 東京大学講師工学系研究科社会基盤学専攻 } \\
3\end{array}$ フェロー \\
工博 & 東京大学教授工学系研究科社会基盤学専攻
\end{tabular}

火力発電所の排水用放水路がある（図-1). この放水路を 境に堤防の天端高さが異なっており，北側では T.P.+4.2m，南側ではT.P.+6.0mとなっている. 2011年東北 津波では, 天端の低い堤防のほとんどが倒壊したが, 天 端の高いものは鮫川河口南側の海岸で一部に天端通路と 裏法の破壊・流出が見られたのみであった（佐藤ら， 2011). また, 小名浜では $42 \mathrm{~cm} の$ 地盤沈下が観測されて おり, 勿来海岸でも同程度の地盤沈下があったことが推 察される。

\section{(2) 航空写真の分析}

航空写真により津波による砂州の変化の様子を調べ た. 津波前後での海岸地形の変化は河口南側に比べて北 側で激しいことがわかった，河口北側においては，発電 所放水路を境に侵食傾向が大きく異なり, 放水路より北

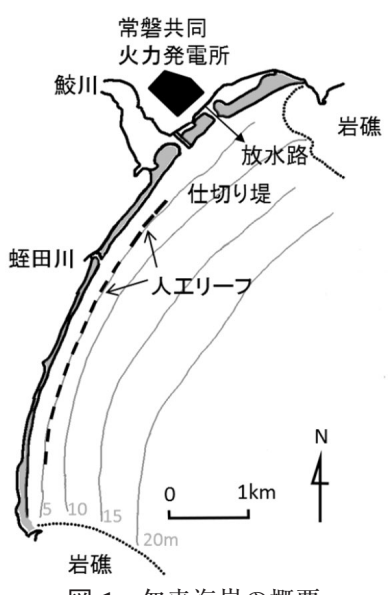

図-1 勿来海岸の概要 
の海岸で特に激しい砂州の浸食が見られる(図-2).この ことから，堤防高の差異が津波による土砂移動に影響を 与えていることが考えられる. 一方, 鮫川河口では砂州 が完全に消失していることが確認できる.

侵食を受けたこれらの砂州は半年後には回復の様子が 見られるが (図-2c)，北側では津波前と比較して $200 \mathrm{~m}$ どの汀線後退があり、砂州全体が陸側へ移動している。 河口砂州も津波以前とは異なった形状になっている。

\section{（3）深浅測量データの分析}

\section{a) 深浅測量データの概要}

福島県による深浅測量データを用いて津波による断面 変化や土砂量変化を求めた. 深浅測量デー夕は $500 \mathrm{~m} ヒ ゚ ッ$ チで汀線付近から $1100 \mathrm{~m}$ 沖まで半年〜2年おきに測定され ている。本分析に用いる深浅測量データの範囲は図-3に 示すとおりである.

\section{b) 断面形状の変化}

2009年8月と2011年9月の深浅測量データを用い、図-3 の断面1から4について津波前後での断面形状の変化を調 べた. 天端高4.2mの堤防前の断面1（図-4a）は，全体的 に底面が低下しており砂州前面で特にそれが大きい. 水 深が深くなるにつれほぼ一様な低下となっており, これ は地盤沈下に起因するものと推測される.

天端高6.0mの堤防前の断面2（図-4b）では4.2mの堤防 前に比べて砂州の侵食量が小さく，100４00mの辺りで 侵食, 400〜600m沖で堆積がみられ，侵食された土砂が 沖方向へも運ばれた可能性が考えられる。 また $4.2 \mathrm{~m}$ 题防

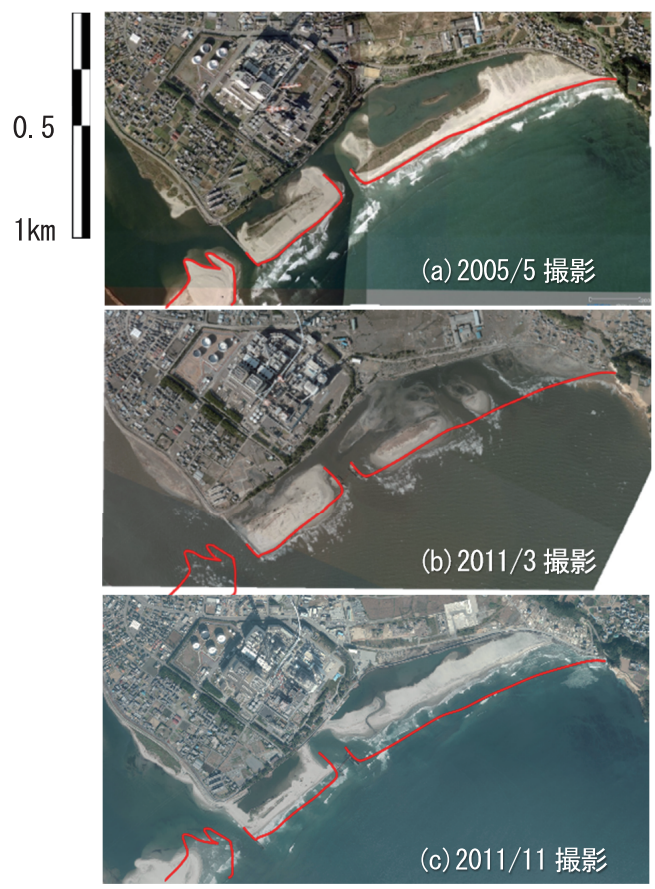

図-2 勿来海岸北部の航空写真
前の断面と同じく水深が深いところでは地盤沈下の影響 のみが現れていると考えられる.

鮫川河口部の断面3（図-4C）では, 河口砂州が大きく 侵食されているほか, 水深の深いところにおいても断面 変化がみられる，津波は河川上流約 $8 \mathrm{~km}$ まで遡上し，津 波直後は河口砂州が完全に流されていた（図-2b）ことも 踏まえると, 河川を遡上・流下する津波による土砂移動 は, 堤防のある断面に比べて非常に大きいと考えられる.

南部の断面4（図-4d）では断面形状の変化は北部に比 ベて小さく，ほぼ一様に0.4m前後であるので地盤沈下に よる変化のみであったと考えられる．津波の越流が少な

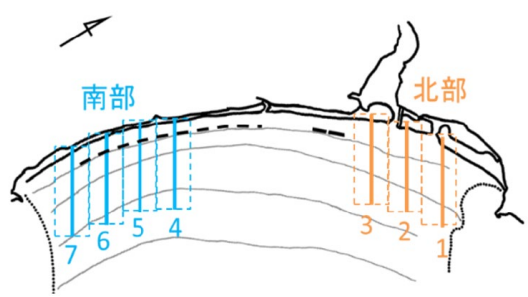

図-3 深浅測量デー夕の範囲
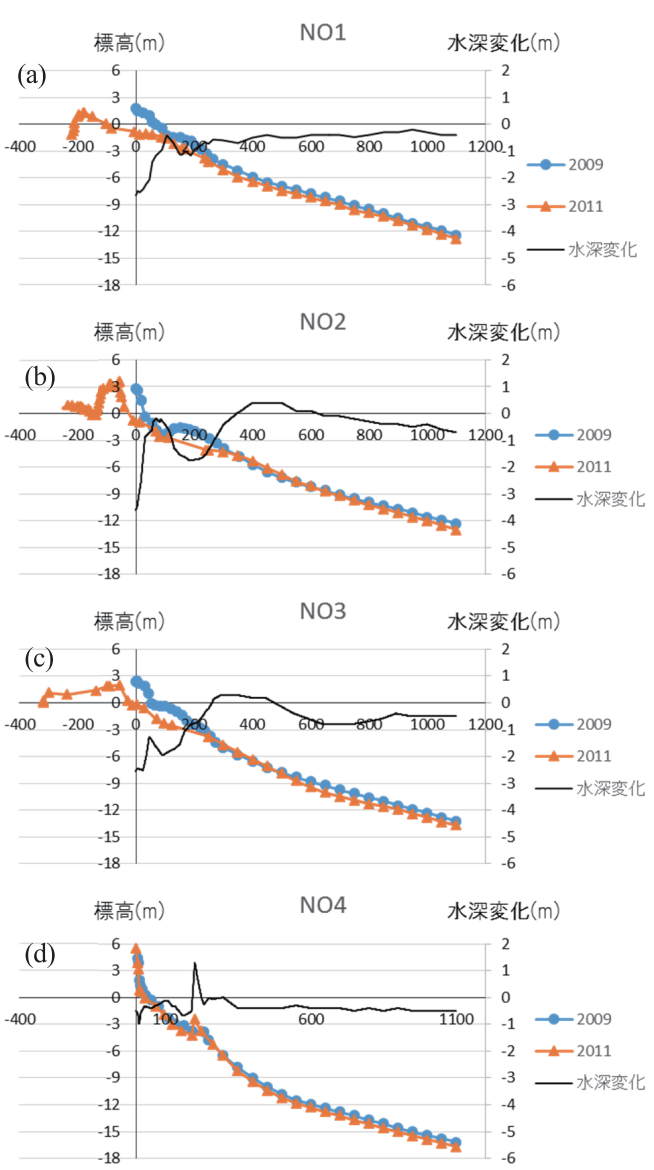

図-4 深浅測量データによる断面地形の変化 
かったことと人エリーフの存在により, 津波による土砂 移動の程度は短期間に回復できる程度に収まったと考え られる。

また, これらとの比較のため, 津波以前の水深変動を 計算した．図-5に示すのは，1989年～1999年までの水深 変化量の変動のRM S值を平均水深ごとに並べたものであ る. 水深 $8 \mathrm{~m}$ 以深では変動が $0.2 \mathrm{~m}$ 以下と低くこの辺に底質 の移動限界水深があると考えられるが，津波後では移動 限界水深を超えた範囲でも変動が見られる.

\section{c) 土砂量変化}

続いて総土砂量の変化を調べるため, 測量範囲を図-3 の通りに南部・北部に分割し，2009年12月を基準として 土砂量の経年変化を計算した（図-6)。これによると，15 年間で土砂量は北部南部ともに減少傾向にあり, 土砂減 少量は1年あたり北部で約 $2.0 \times 104 \mathrm{~m}^{3}$ ，南部で約 $1.3 \times 10^{4}$ $\mathrm{m}^{3}$ であった．津波前後での土砂変動量はこれを大きく上 回っていることがわかる.

平均水深の変化を見ると北部での津波直後の変動は地 盤沈下ょり大きく, 南部では地盤沈下とほほ同等である ことから, 北部での土砂量変化は津波, 地盤沈下両方に よること, 南部ではほぼ地盤沈下のみによるものと考え

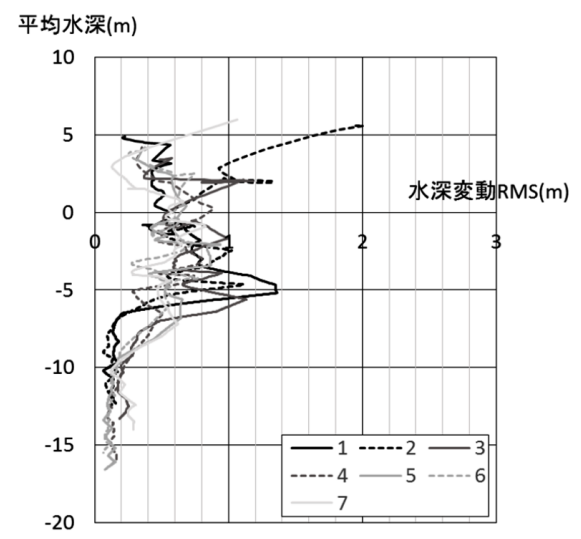

図-5 1989年～1999年の水深変動のRM S值と平均水深
られる. 深浅測量は砂州の前面から行われているため流 された砂州の大部分については含まれていないことを考 慮すると，北部においては津波による土砂量変化は更に 大きいと推測できる，一方，南部では津波直後（2011年） の地盤沈下による土砂量減少のほかに2011年から2012年 にかけて大きな減少が見られる. 勿来海岸では漂砂の卓 越方向が北向きであることから，侵食を受けた北部海岸 および河口部へ沿岸漂砂により土砂が移動したものと考 えられる，砂州の回復量のオーダーは約300万 $\mathrm{m}^{3}$ 程度で あると見積もれるため南部から流出した土砂の一部は砂 州の回復に使われたと推測される.

\section{3. 津波による地形変化の数値解析}

\section{（1）地形変化解析の概要}

深浅測量の結果から明らかになった津波による地形変 化の過程を明らかにするため, 数值モデルによる検討を 行った。ここでは, 測量データが存在する各断面を対象 として，1次元地形変化モデルによる再現計算を実施した. 計算結果には津波の平面挙動による効果が十分に反映さ れないが, 各代表地形の土砂輸送および地形変化特性に ついて，定量的な知見を得ることが可能と考えられる.

地形変化の解析には，下園ら（2007）によって開発さ れた津波による砂堆の侵食予測モデルを用いた。このモ デルは浅水方程式に基づく汇濫モデルと, 底質水平移流 拡散モデルを組み合わせたものである。底質の流体への 取り込みは無次元掃流力の5/2乗に比例する形の全流砂量 式を用いて評価し, 底質の沈降過程は底面近傍の砂濃度 に適当な仮定を置いてモデル化している。モモ゙ルの詳細 については下園ら（2007）を参照されたい.

以下の計算では, 土砂の中央粒径は $0.30 \mathrm{~mm}$ とし, 底 面の粗度係数は 0.025 としている。 また, 計算では細かい 計算グリッド $(5.0 \mathrm{~m})$ により堤防を地形として考慮し, 堤防を含む後背地では底質の取り込みを常にゼロとして 侵食は生じないものとして計算を行った。 入射波の条件 は，約5km離れて隣接する小名浜港での観測波形を基に

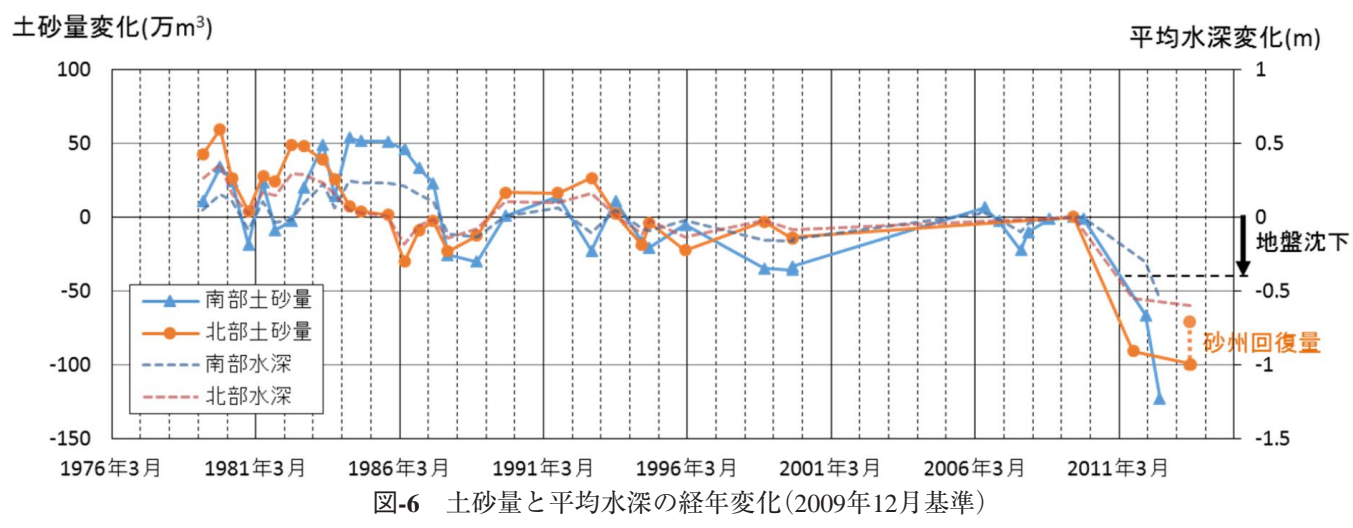


作成した。このようにしたのは，波源モデルによる検討 の結果，小名浜と勿来の波形の差異は波源の不確定性に 比べて小さかったためである。また，地形や構造物条件
による地形変化の違いを明瞭にするため，各断面の計算 には同一の入射波を用いた。 (a) $\ldots \ldots$ original — deformed $\ldots-\cdots$ water surface

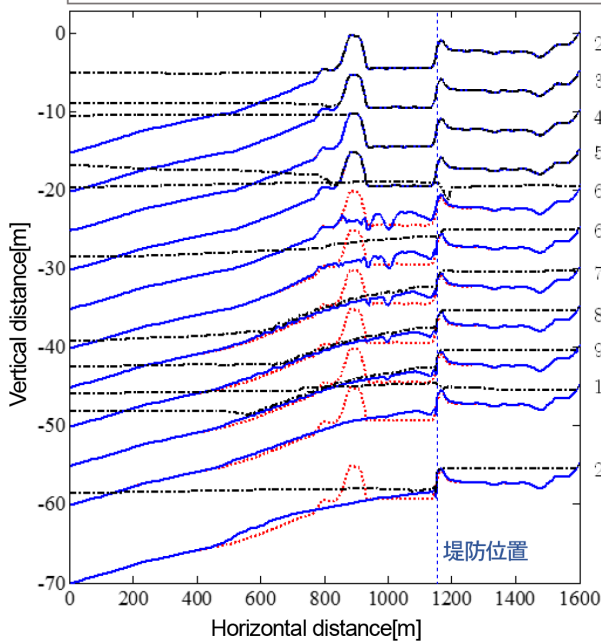

(c)

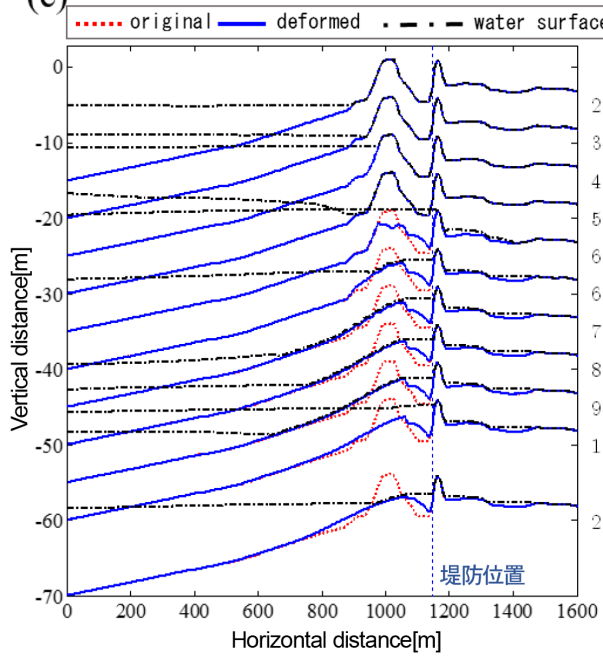

(b) $\ldots \ldots$ original - deformed $\ldots-$ - water surface
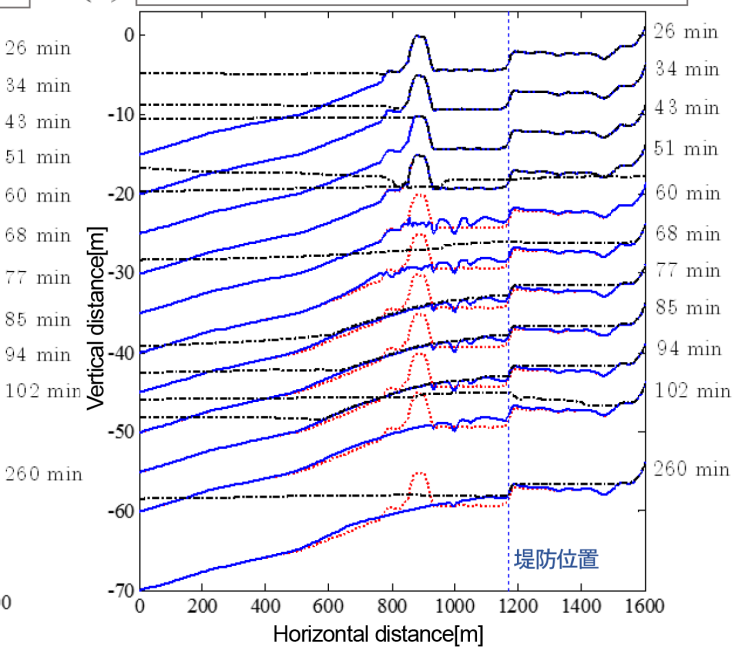

(d)

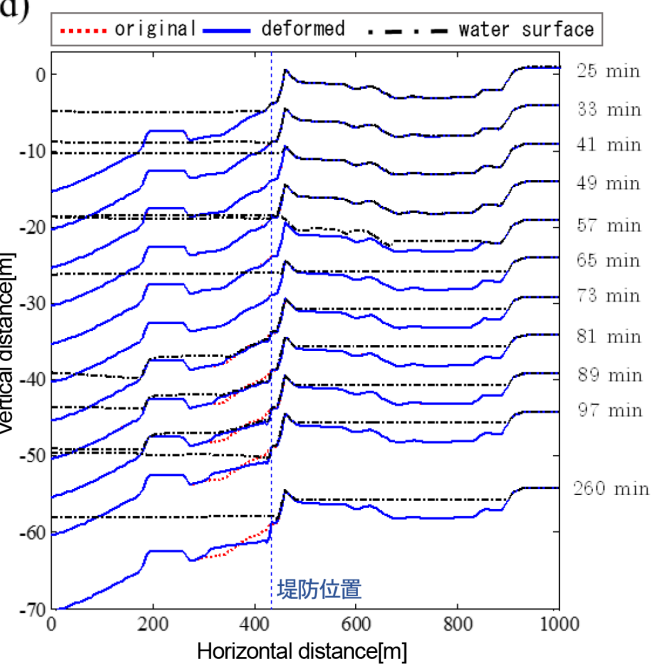

(e)

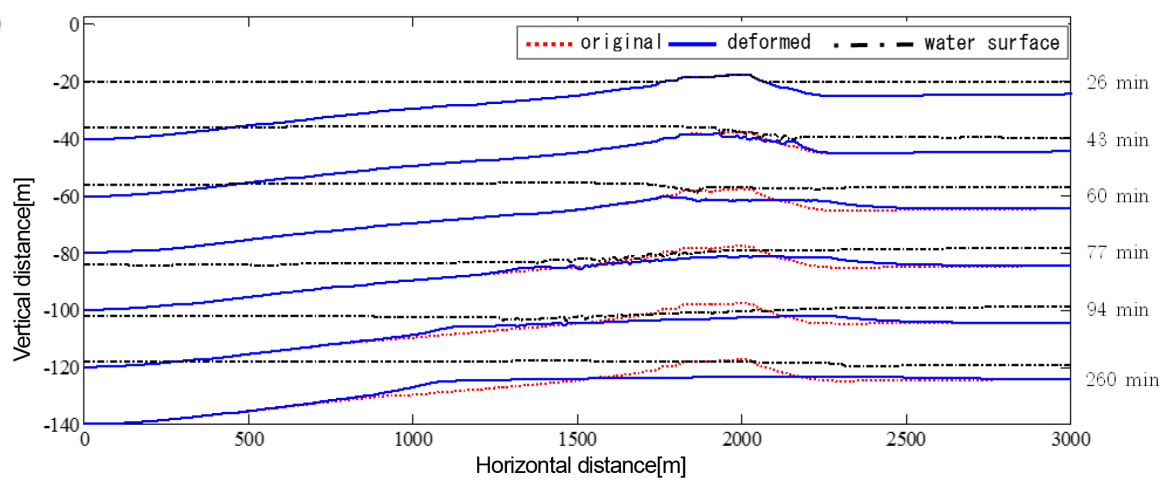

図-7 津波による各断面での地形変化の計算結果：(a) 断面1(堤防あり), (b) 断面1(堤防なし)(c) 断面2(d) 断面4(南部海岸)，(e) 断 面3(鮫川河口部)。各図の右欄外の時間は地震発生後の経過時間を表す. 


\section{(2) 計算結果}

天端高 $4.2 m+T$.P.の堤防前の断面1については津波に よって破堤した箇所が存在するため, 堤防の有無による 地形変化特性の違いを調べるため2通りの計算を行った. いずれの条件でも，押し波時には津波が砂堆を越流する 際に生ずる射流によって砂堆亳法面が大きく侵食される 結果となった，堤防がある場合（図-7(a)）では侵食され た土砂の大部分は流速が低減する堤防前面へと堆積す る. 津波の越流に伴って後背地に流入する土砂量は少な い，その後，引き波時に砂堆前面において射流が発生す ることでこの部分が侵食されて沖側へと土砂が輸送され る，堤防が無い場合（図-7 (b)）には，砂堆の後背部で の流速が大きくなるため, 後背地へと輸送される土砂の 量が増え, 沖側へと運ばれる量が減少する結果となった， 実際に破堤した筒所では，押し波や引き波が平面的に集 中することから，局所的により大きな地形変化が生じた ものと考えられる.

鮫川河口のすぐ北側に位置する断面2では，堤防（天 端高： $6.0 \mathrm{~m}+$ T.P.) の前面には最北の断面と同様に砂堆が 形成されていたが，砂堆頂部はさらに高く，陸側の堤防 との距離は小さい，押し波によって削られた砂堆裏法面 の土砂は，堤防越流がわずかなために堤防背後の陸域に 流入することは殆どなく，すぐ背後に堆積する．引き波 時には, 後背地への越流が小さいため, 砂堆部を沖側へ と流下する水量が大きい. 砂堆の侵食は最北部に比べて やや小さく, これは深浅測量の結果とも一致している. 震災後の測量結果で確認された水深8mあたりでの堆砂は 断面に隣接する川の影響など平面的影響によるものと考 えられる。

鮫川河口の断面3（図-7(e)）では，押し波時に砂州を 越えて河道を遡上する津波によって砂州の大部分が侵食 され砂州上流側の深い水域へと堆積している．引き波時 には反対に河道を流下する流れによって砂州の土砂は沖 側へと運ばれる。繰り返し来襲する同規模の津波によっ て，このような上下流側への土砂輸送が規模を小さくし ながら繰り返され砂州の土砂が両側へと広がっていく. 震災後の測量結果ではこれほど大きな堆積が見られない のは，沖へと運ばれた土砂が波浪の作用によって河口へ と輸送され数か月を経て砂州を再形成しているためであ ると考えられる。しかしがら，水深8mの範囲ではわず

表-1 津波による陸および海側への土砂移動 $\left(\mathrm{m}^{3} / \mathrm{m}\right)$

\begin{tabular}{l|c|c|c|c|c}
\hline & $\begin{array}{c}\text { 断面1 } \\
\text { (堤防有) }\end{array}$ & $\begin{array}{c}\text { 断面1 } \\
\text { (堤防無) }\end{array}$ & 断面2 & 断面4 & $\begin{array}{c}\text { 鮫川 } \\
\text { 河口 }\end{array}$ \\
\hline 沖 (8m以深) & $1.3 \times 10^{0}$ & $1.2 \times 10^{0}$ & $8.0 \times 10^{-2}$ & $7.2 \times 10^{-2}$ & $2.7 \times 10^{2}$ \\
\hline 陸 (堤内地) & $2.2 \times 10^{1}$ & $3.7 \times 10^{1}$ & $7.4 \times 10^{-1}$ & $2.3 \times 10^{0}$ & $6.1 \times 10^{2}$ \\
\hline
\end{tabular}
鮫川河口における陸の值は河道内への移動量を表す
かに堆積が見られ，これは通常波浪による移動限界水深 を越えて沖側へと輸送されたものがこの過程で残存した ものと考えられる.

鮫川よりも南側の断面4（図-7 (d)) では, 砂州はなく 汀線から $200 \mathrm{~m}$ 程度沖側には人工リーフが設置されてい る。計算により繰り返し来襲した津波の作用によって汀 線付近の土砂が沖側へと運ばれていることが分かるが, この土砂輸送は人工リーフより岸側の範囲に留まってい る.このことから, その後の通常波浪の作用によって短 い期間で再び平衡断面に戻り，津波前後の深浅測量結果 に大きな変化が見られないのはこのためと考えられる.

以上より限界水深以深および陸（堤内地, 及び河道内） 側への土砂移動を計算したものを図-1にまとめた．沖へ の移動は陸への移動に比べ小さく無視できる程度である ことがわかった. 陸への移動については堤防の有無や高 さによっても異なり, 河川では大量の移動があったこと がわかる．また，断面1及び2については砂州背後にも堆 積がみられていた。 こうした堤内地や河道, 砂州背後へ の移動土砂は通常の波浪では再び砂州へと戻ることはな いものと考えられる.

\section{4. おわりに}

勿来海岸での津波による土砂侵食機構について深浅測 量デー夕と数值計算から分析をおこなった. 主な結論は 以下の通りである。

(1) 勿来海岸における津波による土砂移動は海岸堤防の 高さや人工リーフ, 砂州の存在によって大きく異なる.

（2）津波による侵食土砂量は過去15年間の侵食量に比べ て大きく, 南部海岸ではほぼ地盤沈下のみによるもの であるが，北部海岸では地盤沈下以外に河道内や砂州 背後などへの土砂移動の影響が無視できない.

（3）北部海岸での津波による大規模な侵食を補う形で, 津波発生以降に南部海岸から北部海岸へ大量の土砂輸 送が生じている.

\section{謝辞}

本研究の一部は, JSPS科研費 26820199の助成を受けた ものである。ここに記して謝意を表す.

\section{参 考 文 献}

梶村 徹 - 佐藤慎司 - 中村匡伸 - 磯部雅彦・藤田 龍 (2001)： 鮫川 · 勿来海岸流砂系の土砂動態と長期海浜過程, 土木 学会論文集, No.691/II-57, pp.121-132.

佐藤壃司・武若 聡・劉 海江・信岡尚道 (2011)：2011年東 北地方太平洋沖地震津波による福島県勿来海岸における 被害, 土木学会論文集B2 (海岸工学), Vol. 67, No.2, pp. | 1296-I 1300

下園武範・佐藤懭司・田島芳満（2007）：津波による堆砂の侵 食に関する研究，海岸工学論文集，第54巻, pp.511-515. 